\title{
PARTISIPASI MASYARAKAT DALAM PENGEMBANGAN AGROWISATA DAN DAMPAKNYA TERHADAP SOSIAL EKONOMI MASYARAKAT (Studi Kasus pada Agrowisata Kampung Flory, Sleman, Yogyakarta)
}

\author{
COMMUNITY PARTICIPATION IN DEVELOPMENT OF AGROTOURISM \\ AND ITS IMPACT ON THE SOCIAL ECONOMIC COMMUNITY \\ (Case Study in Kampung Flory Agrotourism, Sleman, Yogyakarta)
}

\author{
Zaqiah Ramdani*, Tuti Karyani \\ Program Studi Agribisnis, Fakultas Pertanian, Universitas Padjadjaran \\ *E-mail: zaqiah16001@mail.unpad.ac.id \\ (Diterima 07-04-2020; Disetujui 04-06-2020)
}

\begin{abstract}
ABSTRAK
Kabupaten Sleman, Yogyakarta memiliki potensi pariwisata yang menjadi tujuan bagi wisatawan lokal maupun mancanegara. Kampung Flory merupakan salah satu objek wisata di Kabupaten Sleman yang mengusung konsep back to nature dan wisata berbasis masyarakat atau bisa juga disebut dengan community based tourism (CBT). Penelitian dilakukan bertujuan untuk mengetahui partisipasi masyarakat yang terlibat dalam pengembangan Kampung Flory dan dampaknya terhadap kondisi sosial ekonomi masyarakat. Penelitian ini menggunakan pendekatan kualitatif dengan studi kasus. Penentuan subjek penelitian secara purposive dan data dianalisis melalui metode observasi, wawancara, studi pustaka, dokumentasi, dan skala likert. Hasil analisis menunjukkan bahwa partisipasi masyarakat dalam tahapan perencanaan dan evaluasi dalam kategori sedang atau baik, sedangkan untuk tahapan pelaksanaan dan pemanfaatan hasil sudah sangat baik, hanya masyarakat yang terlibat masih belum banyak, sehingga perlu adanya optimalisasi sumber daya manusia yang terlibat. Dampak sosial ekonomi yang dirasakan oleh masyarakat Kampung Flory diantaranya dapat bekerjasama antar sesama warga dengan bergotong royong, dapat meningkatkan wawasan dan ilmu pengetahuan, mampu meningkatkan pendapatan, dan mampu menciptakan lapangan kerja sehingga mengurangi tingkat pengangguran dan kemiskinan.
\end{abstract}

Kata kunci: Kampung Flory, Partisipasi Masyarakat, Community Based Tourism (CBT), Dampak Sosial Ekonomi

\begin{abstract}
Sleman Regency, Yogyakarta has a tourism potential that is a destination for local and foreign tourists. Kampung Flory is one of the attractions in Sleman Regency that carries the concept of back to nature and community-based tourism (CBT). The study was conducted aiming to determine the participation of the community involved in the development of Kampung Flory and its impact on the socio-economic conditions of the community. This research uses a qualitative approach with case study. Determination of the research subject purposively and the data were analyzed through methods of observation, interviews, literature study, documentation, and likert scale. The analysis showed that community participation in the planning and evaluation stages was in the moderate or good category, as for the stages of implementation and utilization of the results it has been very good, it's just that in the communities involved there are still not many, so it is necessary to optimize the human resources involved. The socio-economic impacts felt by the people of Kampung Flory include being able to work together with fellow citizens by working together, being able to increase knowledge and knowledge, being able to increase income, and being able to create jobs so as to reduce unemployment and poverty.
\end{abstract}

Keywords: Kampung Flory, Community Participation, Community Based Tourism (CBT), SocioEconomic Impacts 


\section{PENDAHULUAN}

Indonesia merupakan negara berkembang dan dinobatkan sebagai negara agraris yang memiliki potensi sumber daya alam yang melimpah yang dapat dimanfaatkan ke dalam berbagai sektor salah satunya adalah pariwisata. Diketahui bahwa pariwisata merupakan sektor ekonomi dan jasa dengan tingkat pertumbuhan dan perkembangan yang terpesat di dunia. WTTC (World Travel and Tourism Council) tahun 2017 melaporkan bahwa sektor pariwisata mampu menyumbang hingga 10\% dari total Produk Domestik Bruto (PDB) dunia (UNWTO, 2018).

Perkembangan pariwisata di Indonesia semakin meningkat setiap tahun, terbukti dengan jumlah wisatawan mancanegara yang setiap tahunnya mengalami peningkatan dan berdampak terhadap penambahan devisa negara seperti yang terlihat pada Tabel 1 .

Tabel 1. Jumlah Kunjungan Wisatawan Mancanegara dan Penerimaan Devisa Tahun 2012-2017

\begin{tabular}{ccccc}
\hline Tahun & Jumlah Wisman & Pertumbuhan (\%) & $\begin{array}{c}\text { Penerimaan } \\
\text { Devisa (Juta USD) }\end{array}$ & Pertumbuhan (\%) \\
\hline 2012 & 8.004 .462 & 5,16 & 9.121 & 6,62 \\
2013 & 8.802 .129 & 9,97 & 10.054 & 10,23 \\
2014 & 9.435 .411 & 7,19 & 11.166 & 11,06 \\
2015 & 10.406 .759 & 10,29 & 12.226 & 9,49 \\
2016 & 12.023 .971 & 15,54 & 12.440 & 1,75 \\
$2017^{*}$ & 14.039 .799 & 16,77 & 15.240 & 22,51 \\
\hline
\end{tabular}

Sumber: Kementerian Pariwisata, 2018

Pada Tabel 1 dapat diketahui bahwa dari tahun 2012 sampai 2017, jumlah wisatawan mancanegara yang berkunjung ke Indonesia cenderung terus mengalami peningkatan. Wisatawan mancanegara yang berkunjung pada tahun 2016 mencapai 12.023.971 orang, jumlah wisatawan naik sebesar $15,54 \%$ dari tahun sebelumnya. Sehingga, hal tersebut berpengaruh positif terhadap peningkatan penerimaan devisa negara.

Bagi negara berkembang, sektor pariwisata memiliki potensi yang besar dan memegang peranan yang sangat penting dalam menunjang perekonomian negara, yaitu sebagai sumber penyumbang devisa negara, mampu menciptakan lapangan kerja, mampu membuka kesempatan berwirausaha, dan juga mampu mengurangi tingkat kemiskinan dalam rangka meningkatkan kesejahteraan dan kemakmuran masyarakat (Besra, 2012).

Pariwisata dunia saat ini banyak mengarah pada konsep back to nature. Suasana alamiah dari sektor pariwisata 
dipandang manusia sebagai tempat liburan yang cocok untuk merelaksasikan dirinya dari kegiatan sehari-hari, di mana pada dasarnya manusia merupakan bagian dari alam. Konsep ini sesuai dengan kondisi alam Indonesia sehingga pengelola perlu mengembangkan destinasi wisata dengan konsep berbasis pedesaan "back to nature" atau kembali ke alam sebagai daya tarik pengunjung (Syamsiyah et al, 2019).

Daerah Istimewa Yogyakarta adalah salah satu daerah yang memiliki potensi wisata yang berkembang pesat sehingga menjadi tujuan utama wisata dunia yang sangat populer. Beberapa faktor yang menjadi daya tarik, antara lain telah melahirkan sebuah konsep berbasis "back to nature" yang mampu mengemas keindahan alam pedesaan, keanekaragaman budaya yang unik, harga yang relatif murah, dan sentuhan nilainilai kearifan lokalnya serta masyarakat yang ramah menjadikan daya tarik tersendiri bagi masyarakat dalam maupun masyarakat luar untuk mengunjungi Yogyakarta.

Kabupaten Sleman merupakan salah satu kabupaten di Daerah Istimewa Yogyakarta yang memiliki perkembangan pariwisata yang cukup baik dan memiliki daya tarik tersendiri.
Terdapat sebanyak 46 destinasi wisata yang kemudian dapat diklasifikasikan menjadi tiga produk wisata, yaitu wisata budaya, museum, dan wisata alam serta objek lainnya. Selengkapnya terdapat dalam Tabel 2.

Tabel 2. Potensi dan Daya Tarik Wisata Kabupaten Sleman tahun 2017

\begin{tabular}{clcc}
\hline No & $\begin{array}{l}\text { Produk } \\
\text { Wisata }\end{array}$ & Jumlah & $\begin{array}{c}\text { Presentase } \\
\mathbf{( \% )}\end{array}$ \\
\hline 1. & Budaya & 9 & 19,57 \\
\hline 2. & Museum & 10 & 21,74 \\
\hline 3. & $\begin{array}{l}\text { Alam dan } \\
\text { wisata lainnya }\end{array}$ & 27 & 58,69 \\
\hline & Jumlah & $\mathbf{4 6}$ & $\mathbf{1 0 0}$ \\
\hline
\end{tabular}

Sumber: Dinas Pariwisata, 2018

Tabel 2 menunjukkan bahwa $58,69 \%$ pariwisata yang ada di Kabupaten Sleman adalah wisata alam dan wisaya lainnya. Hal tersebut menunjukkan bahwa kabupaten ini memiliki potensi untuk mengembangkan pariwisata khususnya wisata bernuansa alam. Salah satu potensi wisata alam yang dimiliki di wilayah Kabupaten Sleman adalah Kampung Flory yang telah aktif sejak tahun 2016. Wisata ini terletak di antara dua wilayah desa, yaitu Desa Tridadi dan Desa Tlogoadi, Kabupaten Sleman, Daerah Istimewa Yogyakarta.

Kampung Flory merupakan kawasan agrowisata yang terletak di dekat pusat pemerintahan Kabupaten Sleman. Agrowista ini didirikan atas 


\section{PARTISIPASI MASYARAKAT DALAM PENGEMBANGAN AGROWISATA \\ DAN DAMPAKNYA TERHADAP SOSIAL EKONOMI MASYARAKAT \\ Zaqiah Ramdani dan Tuti Karyani}

dasar inisiatif masyarakat setempat dengan pendekatan pembangunan pariwisata yang mengedepankan masyarakat lokal dengan harapan mampu menjadikan kegiatan wisata ini memberikan nilai-nilai yang bermanfaat tinggi bagi masyarakat sekitar karena posisi masyarakat dalam pembangunan wisata menjadi bagian penting. Sehingga hal tersebut mampu menumbuhkan adanya rasa tanggung jawab dan sikap memiliki.

Alasan lain dibangunnya wisata Kampung Flory dengan melihat kekhawatiran generasi muda pertanian saat ini banyak yang lebih memilih untuk bekerja di bidang lain dibandingkan harus ikut membantu menjadi petani. Kampung Flory ini bukan hanya menawarkan pertanian saja, melainkan menyediakan beragam arena outbound, homestay, dan aneka kuliner yang melibatkan nilai-nilai budaya serta kearifan lokal. Para pengunjung dapat menikmati secara langsung mencoba praktik budidaya pada area pertanian dari agro buah, tanaman hias, dan membeli bibit tanaman yang tersedia.

Pola pengembangan Kampung Flory dilakukan dengan mengikutsertakan peran atau partisipasi masyarakat di wilayah objek wisata setempat dalam menunjang usaha wisata tersebut. Keterlibatan masyarakat lokal dalam pelaksanaan pengembangan usaha wisata diharapkan mampu mengembangkan interaksi positif dalam berbagai kegiatan untuk menjaga eksistensi objek wisata (Nisa et al, 2019). Partisipasi ini diperlukan pada setiap pelaksanaan karena masyarakat lokal merupakan komponen atau unsur utama yang perlu diikutsertakan dalam pengembangan wisata itu sendiri.

Pradini (2019) menjelaskan bahwa partisipasi masyarakat adalah sebuah komponen terpenting dalam upaya kegiatan proses pemberdayaan dan kemandirian. Pengembangan pariwisata berbasis masyarakat akan berjalan baik jika masyarakat setempat secara sadar melakukan kegiatan berkaitan dengan pengembangan pariwisata. Dengan masyarakat mau berpartisipasi dalam pengembangan pariwisata tentunya akan berpengaruh positif pada bidang sosial maupun ekonomi, sehingga mampu meningkatkan kualitas hidupnya.

Kampung Flory telah mencoba mengedepankan pendekatan Community Based Tourism (CBT) sebagai basis pengelolaan pariwisatanya. CBT adalah salah satu konsep utama dalam pengembangan pariwisata yang 
merupakan suatu bentuk keterlibatan masyarakat dalam proses pengembangan pariwisata itu sendiri yang mana disalurkan oleh masyarakat secara sukarela berdasarkan kesadaran diri masyarakat sehingga dapat terjaga keberlanjutan wisata tersebut (Kriska et al, 2019). Pada dasarnya, konsep CBT menempatkan masyarakat sekitar sebagai pelaku utama yang melakukan seluruh kegiatan kepariwisataan melalui pemberdayaan masyarakat, sehingga manfaat yang didapatkannya diprioritaskan untuk masyarakat itu sendiri (Rizkianto dan Topowijono, 2018).

Oleh karena itu, penelitian ini bertujuan untuk menggali lebih dalam mengenai kawasan Kampung Flory. Secara spesifik penelitian ini memiliki dua tujuan, yaitu mengetahui tingkat partisipasi masyarakat sekitar dalam pengembangan kawasan Kampung Flory dan mengetahui dampaknya terhadap kehidupan sosial ekonomi masyarakat.

\section{METODE PENELITIAN}

Penelitian ini dilaksanakan pada bulan Oktober - Desember 2019 di Kampung Flory, Sleman, Yogyakarta. Desain penelitian yang digunakan adalah desain kualitatif dengan menggunakan pendekatan studi kasus (case study). Teknik studi kasus akan melibatkan peneliti untuk menyelidiki lebih dalam dan menyeluruh terhadap perilaku seorang individu (Bungin, 2010). Metode yang digunakan adalah metode deskriptif yaitu menjabarkan gambaran mengenai suatu kejadian atau situasi tertentu.

Data yang digunakan adalah data primer dan sekunder. Data primer terdiri atas data yang diperoleh secara langsung di lapangan melalui wawancara mendalam baik dengan informan pengelola, masyarakat, maupun Dinas Pariwisata Kabupaten Sleman. Teknik pengumpulan data dilakukan dengan cara observasi, wawancara mendalam (depht interview), triangulasi dan studi kepustakaan.

Pengukuran fenomena sosial terkait partisipasi masyarakat di sekitar terhadap pengembangan kawasan Kampung Flory menggunakan skala likert yang nantinya akan diinterpretasikan secara deskriptif di mana menurut Sugiyono (2014), skala likert dapat digunakan untuk mengukur sikap, pendapat, dan persepsi seseorang atau sekelompok orang tentang fenomena sosial. Adapun skor kriteria yang digunakan terlihat pada Tabel 3. 
Tabel 3. Kriteria Penilaian Skala Likert

\begin{tabular}{cc}
\hline Skor Skala Likert & Interpretasi \\
\hline 1 & Sangat tidak setuju \\
2 & Tidak setuju \\
3 & Kurang setuju \\
4 & Setuju \\
5 & Sangat setuju \\
\hline
\end{tabular}

Menurut Riduan (2002), untuk melakukan penarikan kesimpulan dapat diambil dari perhitungan skala likert dengan menggunakan rumus jenjang skor:

1. Menentukan Nilai Indeks Minimum

Nilai indeks minimum $=$ Skor minimun $\mathrm{x}$ jumlah pertanyaan $\mathrm{x}$ jumlah responden

2. Menentukan Nilai Indeks Maksimum Nilai indeks maksimum $=$ Skor maksimum $\mathrm{x}$ jumlah pertanyaan $\mathrm{x}$ jumlah responden

3. Menentukan Interval

Interval $=$

$\underline{\text { Spertanyaan (skor max - skor min } x \sum \text { responden }}$ Ekategori

Setelah dihitung menggunakan rumus jenjang skor, maka maka posisi keputusan penilaian memiliki rentang skala sebagaimana terlihat pada Tabel 4 dan 5 .

Tabel 4. Skor Nilai Untuk Tiga Pertanyaan

\begin{tabular}{ccc}
\hline Skor & $\begin{array}{c}\text { Interpretasi } \\
\text { Hasil }\end{array}$ & $\begin{array}{c}\text { Jawaban } \\
\text { Informan }\end{array}$ \\
\hline $138-322$ & Rendah & Kurang baik \\
$323-506$ & Sedang & Baik \\
$507-690$ & Tinggi & Sangat baik \\
\hline
\end{tabular}

Tabel 5. Skor Nilai Untuk Empat Pernyataan

\begin{tabular}{ccc}
\hline Skor & $\begin{array}{c}\text { Interpretasi } \\
\text { Hasil }\end{array}$ & $\begin{array}{c}\text { Jawaban } \\
\text { Informan }\end{array}$ \\
\hline $184-429,3$ & Rendah & Kurang baik \\
$430,3-674,6$ & Sedang & Baik \\
$675,6-920$ & Tinggi & Sangat baik \\
\hline
\end{tabular}

\section{HASIL DAN PEMBAHASAN}

Kampung Flory merupakan kawasan agrowisata yang terletak di antara dua desa yaitu Desa Tridadi dan Desa Tlogoadi, Kabupaten Sleman, Daerah Istimewa Yogyakarta. Awal berdirinya Kampung Flory berupa lahan pertanian yang terdiri atas bermacam tanaman hias yang disebut sebagai wisata taruna tani dan hanya terletak di Desa Tridadi. Seiring berkembangnya minat pengunjung dan ketersediaan lahan milik kas Desa Tlogoadi menyebabkan taruna tani mengembangkan wisatanya berupa outbound dan kuliner di Desa Tlogoadi dan mengajak pemuda-pemudi sekitar untuk mengembangkan kawasan tersebut dengan mengubah nama menjadi Kampung Flory.

$$
\text { Kampung Flory Sleman, }
$$

Yogyakarta memiliki letak yang cukup strategis dan mudah diakses karena berada dekat dengan kawasan pusat pemerintahan Kabupaten Sleman. Hal tersebut tentu menjadi daya tarik sebagaimanya yang dikemukakan oleh Saputra dan Tuti (2015) bahwa motivasi 
konsumen berkunjung yaitu rekreasi dan mereka memutuskan berkunjung ke suatu kawasan karena alasan kemudahan mencapai lokasi.

Aktif sejak tahun 2016, Kampung Flory saat ini terdiri menjadi tiga zona yaitu zona Taruna Tani, Dewi Flory, dan Kuliner Bali nDeso. Taruna Tani fokus kepada pengembangbiakan dan penjualan tanaman hias, Dewi Flory fokus untuk outbound dan homestay, sedangkan Kuliner Bali nDeso fokus untuk menyediakan kuliner khas dengan nuansa pedesaan. Untuk pengelolaan administratif dibentuk struktur holding Kampung Flory yang menaungi tiga manajemen di bawahnya sesuai zona, yaitu Kelompok Taruna Tani, Kelompok Sadar Wisata Dewi Flory, dan Bali nDeso Group yang kesemuanya terdiri atas masyarakat sekitar kawasan Desa Tridadi dan Desa Tlogoadi.

Produk wisata yang ditawarkan oleh Kampung Flory beragam, dari mulai tour wisata berbagai tanaman hias, jembatan goyang, kolam terapi ikan, taman kelinci, outbound darat dan air, homestay, kuliner, dan saat ini sedang merampungkan produk wisata baru yaitu bumi perkemahan. Pengunjung yang datang ke Kampung Flory juga menilai bahwa kesejukan dan keindahan menjadi kekuatan utama yang mampu menarik minat pengunjung untuk datang (Septio dan Tuti, 2019). Fasilitas yang dimiliki Kampung Flory cukup lengkap baik berupa atraksi wisata, pemandangan alam, kuliner, toko oleh-oleh dan sebagainya yang dapat dilihat pada Tabel 6.

\section{Tabel 6. Fasilitas Kampung Flory}

\begin{tabular}{clc}
\hline No & \multicolumn{1}{c}{ Fasilitas } & Jumlah (unit) \\
\hline 1. & Pusat Informasi & 1 \\
2. & Tempat Parkir & 3 \\
3. & Pos Keamanan & 2 \\
4. & Pos Kesehatan (P3K) & 1 \\
5. & Penginapan (homestay) & 2 \\
6. & Tempat makan atau resto & 3 \\
7. & Mushola & 2 \\
8. & Kamar Mandi & 15 \\
9. & Saung atau Limasan & 4 \\
10. & Toko Oleh-Oleh & 1 \\
11. & Bak Sampah Besar & 3 \\
12. & Bak Sampah Kecil & 20 \\
\hline
\end{tabular}

Pengelolaan Kampung Flory masih milik swadaya masyarakat yang saling bergotong royong dibantu oleh berbagai pihak terkait seperti Dinas Pariwisata, Dinas Pertanian, Lembaga Keuangan dan pemerintah desa setempat. Kampung Flory belum dapat dijadikan BUMDes karena letaknya yang berada di antara dua desa sehingga masih banyak yang perlu dikaji bersama dengan pihak terkait. 


\section{PARTISIPASI MASYARAKAT DALAM PENGEMBANGAN AGROWISATA \\ DAN DAMPAKNYA TERHADAP SOSIAL EKONOMI MASYARAKAT \\ Zaqiah Ramdani dan Tuti Karyani}

Partisipasi Masyarakat Sekitar dalam Pengembangan Kampung Flory

\section{Tahap Perencanaan}

Tahap perencanaan merupakan salah satu langkah penting dalam melakukan suatu kegiatan. Perencanaan juga merupakan suatu bentuk adanya keterlibatan masyarakat dalam penyusunan rencana kegiatan untuk memutuskan tujuan-tujuan yang akan dicapai dalam waktu tertentu dan juga menentukan tahapan yang akan dilaluinya.

Tabel 7. Tahap Perencanaan

\begin{tabular}{clc}
\hline No & \multicolumn{1}{c}{ Indikator } & Skor \\
\hline 1. & $\begin{array}{l}\text { Masyarakat yang terlibat dalam } \\
\text { pembentukan kegiatan }\end{array}$ & 132 \\
2. & $\begin{array}{l}\text { Menyampaikan pendapat dalam } \\
\text { kegiatan rapat musyawarah }\end{array}$ & 153 \\
3. $\begin{array}{l}\text { Mengikuti sosialisasi } \\
\text { perencanaan program } \\
\text { pengembangan Kampung Flory }\end{array}$ & 182 \\
\hline \multicolumn{1}{c}{ Total } & $\mathbf{4 6 7}$ \\
\hline
\end{tabular}

Berdasarkan hasil perhitungan, nilai indeks minimum untuk tahap perencanaan adalah 138, dengan nilai indeks maksimum 690, dan interval 184. Hasil partisipasi menunjukan nilai termasuk dalam kategori partisipasi tingkat sedang dengan skor 467.

Keterlibatan masyarakat setempat dalam perencanaan dianggap sudah baik namun masih banyak yang perlu ditingkatkan. Keterlibatan masyarakat dalam pengelolaan Kampung Flory menjadi salah satu tujuan utama yang diinginkan dari pengelola, sehingga pengelola berusaha melakukan perencanaan kegiatan untuk selalu melibatkan masyarakat dalam kegiatan perencanaan hingga akhir kegiatan sebagai karyawan wisata. Tahapan ini sangat begitu mendasar pada partisipasi masyarakat, karena segala apa yang dibahas menyangkut masyarakat secara keseluruhan demi kepentingan bersama. Namun, memang sejauh ini partisipasi masyarakat yang bergabung dalam pengelolaan dirasa belum menyeluruh, sehingga pengelola berupaya memberi peluang-peluang baik berupa kerjasama usaha maupun yang lain agar masyarakat dapat turut aktif dalam mengembangan Kampung Flory.

Pengelola juga merencanakan untuk mengadakan sosialisasi setiap sebulan sekali dalam rangka peningkatan kuantitas sumber daya manusia. Perencanaan yang dilakukan pengelola Kampung Flory ini sudah baik, lebih jauh ke depan dalam proses pendirian dan pengembangan karena berusaha untuk mewujudkan tujuan utama sebelum dibentuknya objek wisata ini sehingga dibutuhkan partisipasi masyarakat lain agar dapat mewujudkannya. 


\section{Tahap Pelaksanaan}

Tahap pelaksanaan merupakan salah satu bentuk keterlibatan masyarakat yang menjadi kunci keberhasilan suatu rencana kegiatan. Bentuk keterlibatan dalam tahap pelaksanaan yang dilakukan di Kampung Flory yaitu ikut kontribusi dalam pelaksanaan kegiatan, pemikiran, waktu, materi, dan keterlibatan langsung yang bertujuan untuk meningkatkan kualitas sumber daya manusia.

Tabel 8. Tahap Pelaksanaan

\begin{tabular}{clc}
\hline No & \multicolumn{1}{c}{ Indikator } & Skor \\
\hline 1. & $\begin{array}{l}\text { Masyarakat yang terlibat dalam } \\
\text { program kegiatan Kampung }\end{array}$ & 132 \\
& $\begin{array}{l}\text { Flory } \\
\text { 2. }\end{array}$ & $\begin{array}{l}\text { Ikut mempromosikan wisata } \\
\text { Kampung Flory } \\
\text { Mengikuti pembinaan masyarakat }\end{array}$ \\
3. & 180 \\
& $\begin{array}{l}\text { melalui pelatihan dan workshop } \\
\text { tenaga kerja }\end{array}$ \\
4. $\begin{array}{l}\text { Ikut melaksanakan program } \\
\text { wisata Kampung Flory }\end{array}$ & 204 \\
\hline \multicolumn{1}{c}{ Total } \\
\hline
\end{tabular}

Berdasarkan hasil perhitungan, nilai indeks minimum untuk tahap pelaksanaan ini adalah 184, dengan nilai indeks maksimum 920, dan interval 245,3. Hasil partisipasi menunjukan nilai termasuk dalam kategori partisipasi tingkat tinggi dengan skor 714 .

$$
\text { Dalam tahap pelaksanaan, }
$$
Kampung Flory terbagi menjadi tiga kawasan yang memiliki manajemen zona masing-masing yaitu zona taruna tani, dewi flory dan kuliner bali ndeso. Secara keseluruhan semua program yang ada di wisata sejauh ini sudah sangat baik dalam pelaksanaannya. Proses pelaksanaan pengembangan objek wisata bukan hanya dilakukan oleh pihak pengelola saja, melainkan juga masyarakat yang tinggal di sekitar objek wisata.

Masyarakat terlibat aktif dalam kegiatan baik sebagai anggota di dalam kepengurusan maupun masyarakat yang berjualan di sekitar kawasan. Pengelola juga turut serta mengajak masyarakat untuk ikut aktif dalam mengikuti pelatihan kepariwisataan yang diadakan oleh dinas setempat maupun Bank Indonesia sehingga membantu dalam proses pengembangan wisatanya.

\section{Tahap Pemanfaatan Hasil}

Tahap pemanfaatan hasil merupakan suatu tolak ukur keberhasilan dalam suatu pencapaian rencana.

\section{Tabel 9. Tahap Pemanfaatan Hasil}

\begin{tabular}{clc}
\hline No & Indikator & Skor \\
\hline 1. & $\begin{array}{l}\text { Merasakan keuntungan dari } \\
\text { program wisata Kampung Flory }\end{array}$ & 222 \\
2. & $\begin{array}{l}\text { Hasil dari kegiatan wisata dibagi } \\
\text { dengan jelas }\end{array}$ & 198 \\
3. & $\begin{array}{l}\text { Mendapatkan informasi laporan } \\
\text { program wisata Kampung Flory }\end{array}$ & 161 \\
4. $\begin{array}{l}\text { Mengikuti pemaparan tercapainya } \\
\text { keberhasilan Kampung Flory }\end{array}$ & 187 \\
\hline \multicolumn{1}{c}{ Total } \\
\hline
\end{tabular}

Berdasarkan hasil perhitungan, indeks minimum untuk tahap pemanfaatan hasil adalah 184, dengan indeks maksimum 920, dan interval 245,3. Hasil partisipasi menunjukan nilai 
termasuk dalam kategori partisipasi tingkat tinggi dengan skor 768.

Keterlibatan masyarakat dalam tahapan pemanfaatan hasil sudah sangat baik. Di mana setiap manajemen pengelola memberikan $2,5 \%$ hasil bersih keuntungan per bulan kepada holding Kampung Flory sebagai uang kas yang digunakan untuk kegiatan pertemuan atau membantu kegiatan desa, dan adanya pembagian hasil homestay yang ditentukan oleh pemilik penginapan. Untuk kawasan Bali nDeso terdapat pembagian keuntungan hasil penjualan Iwa Kalen sebesar 55 : 45 dengan rincian 55\% untuk Kelompok Taruna Tani dan 45\% untuk pemilik Iwa Kalen.

Masyarakat yang turut serta dalam pelaksanaan program wisata juga mendapatkan hasil yang sesuai dengan kesepakatan awal, sehingga dianggap adil.

\section{Tahap Evaluasi}

Tahap ini bertujuan untuk mengetahui apakah pelaksanaan kegiatan yang sudah direncanakan diawal sudah sesuai atau belum, apa yang perlu diperbarui, apa yang perlu ditingkatkan kembali untuk mendapatkan pencapaian yang telah ditentukan.
Tabel 10. Tahap Evaluasi

\begin{tabular}{clc}
\hline No & Indikator & Skor \\
\hline 1. & $\begin{array}{l}\text { Menyampaikan masukan, baik } \\
\text { ide/kritik/saran dalam setiap } \\
\text { evaluasi }\end{array}$ & 157 \\
2. & $\begin{array}{l}\text { Selalu diundang dalam kegiatan } \\
\text { evaluasi Kampung Flory }\end{array}$ & 186 \\
3. & $\begin{array}{l}\text { Selalu semangat untuk } \\
\text { menghadiri kegiatan evaluasi } \\
\text { Kampung Flory }\end{array}$ & 127 \\
\multicolumn{1}{c}{ Total } \\
\hline
\end{tabular}

Berdasarkan hasil perhitungan, nilai indeks minimum untuk tahap evaluasi adalah 138, dengan indeks maksimum 690, dan interval 184. Hasil partisipasi menunjukkan nilai termasuk dalam kategori partisipasi tingkat sedang dengan skor 470 .

Terlihat dalam kegiatan evaluasi masyarakat masih kurang begitu antusias dalam menghadiri kegiatan evaluasi seperti rapat. Partisipasi dalam tahapan ini berkaitan dengan masalah-masalah yang terjadi pada saat pelaksanaan kegiatan wisata secara menyeluruh sehingga dapat dijadikan masukkan untuk pelaksanaan berikutnya.

Kampung Flory memang jarang mengadakan kegiatan evaluasi sehingga tidak heran jika partisipasi masyarakat dalam tahap ini masih rendah. Hal tersebut dikarenakan Kampung Flory terdiri atas tiga manajemen yang berbeda yang memiliki waktu yang berbeda, sehingga pihaknya menganggap apabila 
tidak ada masalah berarti maka tidak diperlukan evaluasi.

\section{Dampak Sosial Ekonomi Masyarakat}

Keberadaan wisata Kampung Flory dalam pengembangan objek wisata secara tidak langsung telah memberikan dampak yang dirasakan oleh masyarakat Desa Tridadi dan Desa Tlogoadi Sleman Yogyakarta, khususnya dampak sosial dan ekonomi. Dampak tersebut merupakan akibat dari adanya partisipasi masyarakat untuk mengembangkan objek wisata Kampung Flory.

Kawasan wisata ini dibentuk dengan konsep Community Based Tourism (CBT) atau pariwisata berbasis masyarakat yang merupakan pelibatan masyarakat dengan memberikan kepastian manfaat yang akan diterima oleh masyarakat melalui upaya perencanaan dan pendampingan yang membela masyarakat lokal, serta kelompok lain yang memiliki minat terhadap kepariwisataan.

\section{Dampak Sosial}

Dampak sosial yang terasa akibat adanya kegiatan pengembangan Kampung Flory oleh masyarakat adalah:

\section{a. Kerjasama \\ Antar Warga Masyarakat \\ Adanya Kampung Flory}

memberikan dampak yang positif juga dalam proses pengembangan objek wisata. Melibatkan masyarakat untuk melakukan pelaksanaan wisata merupakan salah satu tujuan dari objek wisata. Hal ini dapat menimbulkan interaksi dan kerjasama antar warga masyarakat setempat. Mbak Ike selaku staff administrasi Kampung Flory mengatakan:

"Dalam segi pelaksanaannya baik itu kita membangun fasilitas-fasilitas yang kurang, memperbaiki jalan, menjaga kelestarian alam, menjaga kebersihan, dan keamanan selalu melibatkan masyarakat dalam pengelolaannya. Pelaksanaan yang dilakukan masyarakat juga secara bersama-sama atau bergotong royong agar pelaksanaannya pun cepat selesai"

\section{b. Meningkatkan Wawasan dan Ilmu Pengetahuan}

Dalam melakukan pengelolaan objek wisata masyarakat perlu adanya bekal ilmu pengetahuan agar pencapaian yang sudah ditentukan tercapai. Keterlibatan masyarakat sekitar dalam pengelolaan Kampung Flory menjadi tujuan utama yang diinginkan pengelola. Pengelola juga mengadakan pelatihan secara rutin yang dilakukan setiap enam bulan sekali dalam rangka peningkatan kualitas sumber daya manusia bekerja sama dengan lembaga terkait. Hal tersebut diungkapkan oleh Bapak Agus Rohmat Basuki selaku Manager Bali nDes Group: 


\section{PARTISIPASI MASYARAKAT DALAM PENGEMBANGAN AGROWISATA \\ DAN DAMPAKNYA TERHADAP SOSIAL EKONOMI MASYARAKAT \\ Zaqiah Ramdani dan Tuti Karyani}

"minimnya SDM di sini karena keterbatasan masyarakat akan ilmu pengetahuan yang dimiliki. Rata-rata masyarakat di sini mayoritas lulusan SMA jadi mereka kurang mengetahui bagaimana cara mengelola wisata yang baik dan benar. Tapi pihak pengelola di sini tidak tinggal diam, kami pun berusaha selalu mengadakan pelatihan rutin setiap enam bulan sekali, sehingga masyarakat dapat belajar untuk menambah wawasan dan juga pengetahuam yang sudah diberikan"

Selain itu, Mbak Nur sebagai

penjaga joglo oleh-oleh juga mengatakan:

"Awal bekerja di sini saya tidak tahu apa-apa mbak, tidak tahu cara kerjanya. Akhirnya setelah pihak pengelola memberikan sosialisasi terlebih dahulu, saya pun ikut berpartisipasi dalam proses pengembangannya. Di sini mendapatkan banyak pengalaman karena diberikan juga pelatihan-pelatihan atau workshop gitu untuk meningkatkan ilmu pengetahuan bagi masyarakat setempat"

\section{c. Sadar akan pembangunan wisata}

Kampung Flory merupakan salah satu objek wisata yang dibangun untuk menyadarkan masyarakat akan pentingnya dunia pertanian karena adanya keprihatinan atas kondisi bahwa banyak generasi muda tidak tertarik dengan bidang pertanian yang identik dengan kotor, rumit, kerja keras, dan hasil yang didapat tidak besar. Pendapat yang sama diungkapkan oleh Ibu Vina:

"Memang betul anak jaman sekarang itu beda sekali dengan orang-orang dulu. Pertanian itu sangatlah penting dimana kita mendapatkan bahan makanan dari usaha-usaha bertani. Banyak sekali anak muda yang tidak ingin bekerja di bidang pertanian ini, hal ini sangat memprihatinkan masyarakat kalangan dewasa"

Selain itu, ungkapan lain disampaikan oleh Bapak Mujiyono selaku pengawas Kampung Flory yang mengatakan:

"Keprihatinan terhadap generasi
muda yang tidak tertarik di bidang
pertanian ini sudah cukup banyak,
maka dari itu kami sebagai pengelola
berusaha untuk terus berinovasi
membuat objek wisata yang bisa
menarik kalangan muda ikut terlibat di
Kampung Flory ini. Karena wisata ini
merupakan sarana wisata yang
diseimbangkan dengan edukasi
pertanian"

\section{Dampak Ekonomi}

Dampak ekonomi yang terasa akibat adanya kegiatan pengembangan Kampung Flory oleh masyarakat adalah:

\section{a. Adanya Peluang Usaha}

Peluang usaha dapat dilihat dari adanya pembangunan objek wisata. Peluang usaha dapat dimanfaatkan oleh masyarakat sekitar khususnya Desa Tridadi dan Desa Tlogoadi. Partisipasi masyakat yang ikut melaksanakan program kegiatan ekonomi seperti berjualan dan bekerja di objek wisata. Hal ini sesuai dengan apa yang disampaikan oleh Mas Lilik Sumanto selaku Sekretaris Kampung Flory yang mengatakan: 
"Awal dibangunnya wisata sangat membuka peluang bagi masyarakat Desa Tridadi dan Desa Tlogoadi. Hal ini dapat dilihat dari banyaknya masyarakat yang bekerja di wisata ini seperti berdagang, menjadi tukang ojeg, menjadi tukang parkir. Semua itu yang bekerja adalah masyarakat desa setempat, pihak pengelola memberdayakan masyarakat desa tujuan untuk mengubah kehidupan masyarakat menjadi lebih baik. Awal mula sebelum bekerja di sini, saya bekerja di media koran mendapatkan penghasilan yang sebulannya bisa mendapatkan Rp.1.000.000 saja. Lalu, setelah adanya Kampung Flory sayang sekali jika saya tidak ikut berpartisipasi dalam proses pengembangannya, apalagi jaraknya dekat dengan rumah saya jadi saya bekerja di dua tempat sekaligus dan itupun tidak bentrok jadwalnya. Jadi hal ini juga dapat membantu penghasilan saya untuk kebutuhan keluarga"

\section{b. Peningkatan Pendapatan}

Banyaknya masyarakat yang terlibat dalam mengembangkan objek wisata menyebabkan pengunjung terus berdatangan hal ini diakibatkan oleh adanya penjualan masyarakat. Pendapat yang diungkapkan oleh Mbak Ratna sebagai pedagang sosis bakar:

\footnotetext{
"Dari tahun ke tahun pendapatan meningkat, apalagi kalo di hari weekend pengunjung pun pasti rame yang datang sehingga hasil yang didapatkan juga meningkat dan di hari weekend pun bisa saja saya menyetok barang lebih banyak juga. Kalo di hari-hari biasa dapat keuntungan mencapai $\mathrm{Rp} 500.000$, dan kalo di hari libur panjang keuntungan yang didapatkan mencapai Rp 1.000.000"
}

Selain itu, ungkapan lain juga disampaikan oleh Mas Rama sebagai penjual binatang umang-umang yang mengatakan:

"Semenjak ada wisata Kampung Flory saya pindah berjualan di sini karena rumah juga dekat ga terlalu jauh penghasilan pun lumayan banyak mbak. Pendapatan yang saya peroleh sudah lebih dari cukup untuk memenuhi kebutuhan saya dan istri. Biasanya saya dapat keuntungan sebesar Rp 800.000 sebulan tapi kalo lagi rame-ramenya apalagi hari libur sekolah bisa mencapai R. 1.500 .000 an. Dan ada juga temen saya yang tadinya menganggur di rumah sekarang sudah memiliki penghasilan sendiri walaupun dia juga berjualan mainan anak-anak seperti mobil, atau robot-robotan"

\section{c. Penyerapan Tenaga Kerja}

Kampung Flory memiliki dampak postitif terhadap pengurangan pengangguran. Selain itu, dapat mendorong masyarakat untuk ikut melakukan kegiatan ekonomi dengan membuka usaha di kawasan objek wisata. Hal tersebut disampaikan oleh Bapak Mujiyono selaku pengawas Kampung Flory:

"Dengan adanya Kampung Flory di desa ini, membuka kesempatan dan membuka lapangan pekerjaan bagi masyarakat untuk ikut serta terlibat dalam proses pengembangan wisata, sehingga mendorong perekonomian yang semakin baik. Tujuan dibentuknya wisata ini untuk memberdayakan masyarakat agar masyarakat yang belum dapat pekerjaan bisa bekerja di sini sehingga 


\section{PARTISIPASI MASYARAKAT DALAM PENGEMBANGAN AGROWISATA \\ DAN DAMPAKNYA TERHADAP SOSIAL EKONOMI MASYARAKAT \\ Zaqiah Ramdani dan Tuti Karyani}

dapat mengurangi terjadinya penganguran. Selain masyarakat dapat bekerja di wisata ini, juga mereka dapat membuka usaha di sekitaran kawasan. Saat ini sudah ada yang berjualan di zona Bali nDeso seperti berjualan mainan anak-anak, makanan sosis bakar, jagung, cilok, siomay, dan lain-lain”,

Dampak sosial ekonomi yang dirasakan oleh masyarakat tersebut tentu menjadi suatu kebanggan tersendiri bagi pengelola karena harapan untuk meningkatkan potensi desa dari, oleh, dan untuk masyarakat bisa sedikit demi sedikit terwujud. Namun, tidak puas sampai di sini karena masih banyak masyarakat yang belum merasakan dampak adanya Kampung Flory sehingga pengelola terus berupaya untuk bersamasama mengajak masyarakat untuk mengembangkan wisata tersebut untuk tujuan kesejahteraan masyarakat.

\section{KESIMPULAN DAN SARAN}

Partisipasi masyarakat dalam tahap perencanaan dan evaluasi sudah cukup baik. Berbeda dengan tahapan pelaksanaan dan pemanfaatan hasil yang sudah sangat baik, hanya saja masyarakat yang terlibat masih sedikit belum terlalu banyak. Oleh karena itu, sumber daya manusia di Kampung Flory masih perlu dioptimalkan kembali, baik dari segi kuantitas dan kualitasnya. Masyarakat di kawasan selalu diprioritaskan oleh pihak pengelola untuk berperan aktif dalam proses pengembangan Kampung Flory karena sesuai dengan tujuan dari objek wisata ini "dari masyarakat, oleh masyarakat, dan untuk masyarakat".

Dampak sosial yang dirasakan masyarakat kawasan Desa Tridadi dan Desa Tlogoadi dengan adanya Kampung Flory yaitu masyarakat dapat bekerjasama antar sesama warga dalam proses pengembangan wisata dengan cara bergotong royong, dapat meningkatkan wawasan dan ilmu pengetahuan masyarakat terkait kepariwisataan, dapat menyadarkan masyarakat dalam maupun luar pentingnya dunia pertanian khususnya kalangan anak muda. Kemudian, dampak ekonomi yang dirasakan masyarakat dalam pengembangan wisata adalah dapat membuka peluang usaha, meningkatkan pendapatan masyarakat, dan dapat menyerap tenaga kerja untuk mengurasi pengangguran yang terjadi.

Saran yang perlu dilakukan oleh pengelola Kampung Flory adalah lebih rutin mengadakan pertemuan dengan masyarakat, misalnya satu bulan sekali untuk membicarakan perkembangan dan inovasi-inovasi yang dapat diterapkan, khususnya untuk pemuda agar tertarik 
dalam proses pengembangan Kampung Flory

\section{UCAPAN TERIMA KASIH}

Terimakasih kepada pihak Kampung Flory, masyarakat Desa Tridadi dan Tlogoadi serta dinas terkait yang telah membantu pelaksanaan penelitian.

\section{DAFTAR PUSTAKA}

Besra, E. (2012). Potensi Wisata Kuliner Dalam Mendukung Pariwisata di Kota Padang. Jurnal Riset Akutansi dan Bisnis, 12(1): 74-101.

Bungin, B. (2010). Penelitian Kualitatif : Komunikasi, Ekonomi, Kebijakan Publik, dan Ilmu Sosial Lainnya. Jakarta: Kencana.

Dinas Pariwisata. (2018). Statistik Kepariwisataan 2017. Yogyakarta: Dinas Pariwisata

Kriska, M., Andiani, K., \& Simbolon, T.G.Y. (2019). Partisipasi Masyarakat Dalam Community Based Tourism di Desa Wisata Puton Watu Ngelak Kabupaten Bantul Community Tourism Village, Bantul Regency. Yogyakarta: Fakultas Pertanian Universitas Gajah Mada.

Nisa, N., Widodo, J. \& Djaja, S. (2019). Partisipasi Gucialit Organisasi Wisata Alam (Gowa) Dalam Pengembangan Agrowisata Kebun The Kertowono di Kecamatan Gucialit Kabupaten Lumajang. Jurnal Pendidikan Ekonomi: Jurnal Ilmiah Ilmu Pendidikan, Ilmu
Ekonomi \& Ilmu Sosial, 13(1): 129134.

Pradini, G., Kausar, D.R.K., \& Alfian, F. (2019). Manfaat dan Hambatan Pengembangan Pariwisata Berbasis Masyarakat di Perkampungan Budaya Setu Babakan. Journal of Tourism Destination and Attraction, 2(2): 11-18.

Riduan. (2002). Skala Pengukuran Variabel-Variabel Penelitian. Bandung: Alfabeta.

Rizkianto, N., \& Topuwijono. (2018). Penerapan Konsep Community Based Tourism Dalam Pengelolaan Daya Tarik Wisata Berkelanjutan. Jurnal Administrasi Bisnis, 58(2): 20-26.

Saputra, Efrizal, dan Karyani. T. (2015). Analisis Keputusan Berkunjung Serta Kepuasan Konsumen Agrowisata Cilangkap. Prosiding Seminar Nasional Pembangunan Inklusif di Sektor Pertanian II. Sumedang: 9 September 2015.

Septio, A. dan Karyani, T. (2019). Visitor Perception About The Sapta Pesona Implementation in Kampung Flory Sleman Yogyakarta. Journal of Business on Hospitality and Tourism, 05(02): 307-317.

Sugiyono. (2014). Metode Penelitian Kuantitatif, Kualitas dan $R \& D$. Bandung: Alfabeta

Syamsiah, N., Sulistyowati, L., Kusno, K. \& Wiyona, S.N. (2019). Identifikasi Risiko Usahatani Mangga Dalam Pengembangan Agrowisata di Kabupaten Cirebon. Jurnal IlmuIlmu Sosial dan Humaniora, 21(1):

[UNWTO] United Nations and World Tourism Organization. (2018). UNWTO tourism highlight 2018 edition. Madrid, New York. 